\title{
O ENDIVIDAMENTO DAS AUTARQUIAS LOCAIS EM PORTUGAL NA ÓTICA DA LEI 73/2013 E A LEI COMPLEMENTAR 101/2000 BRASILEIRA - MUNICÍPIOS E A ADMINISTRAÇÃO PÚBLICA
}

\author{
THE OF INDEBTEDNESS OF LOCAL AUTHORITIES IN PORTUGAL IN LAW 73/2013 \\ OPTICS AND IN BRAZILIAN 101/2000 SUPPLEMENTARY LAW \\ - MUNICIPALITIES AND PUBLIC ADMINISTRATION
}

\begin{abstract}
Pedro Reinaldo Feiten
Mestre em direito pela Universidade de Santa Cruz do Sul - UNISC e pela Universidade do Minho (bragaportugal) - UMINHO. Professor de responsabilidade civil, direito das coisas e direito de família da Universidade

Luterana do Brasil - ULBRA. E-mail: pedro@feiten.com.br
\end{abstract}

Janriê Rodrigues Reck

Doutor em direito pela Universidade do Vale do Rio dos Sinos. Professor do Programa de Pós-Graduação, Mestrado e Doutorado, da Universidade de Santa Cruz do Sul. E-mail: janriereck@ibest.com.br

Recebido em: 22/04/2014

Aprovado em: $12 / 05 / 2016$

Doi: $10.5585 / \mathrm{rdb} . v 14 \mathrm{i} 6.147$

RESUMO: O presente artigo visa abordar a temática do endividamento das Autarquias Locais, em Portugal, a partir da Lei 73/2013, aprovada em 29 de julho de 2013 pela Assembleia da República e com entrada em vigor a partir de 01 de janeiro de 2014. Faz-se uma relação e comparação com o sistema brasileiro, no que tange a lei pátria 101/2000. Ambas as legislações, dentre outras temáticas, tratam do tema do endividamento da célula municipal. A apresentação das possibilidades e formatos, o estudo das nuances e os seus aspectos técnicos e jurídicos, será o objeto deste estudo, junto de definições doutrinárias.

Palavras-Chave: Regime Financeiro das Autarquias. Lei de Responsabilidade Fiscal. Lei 73/2013 - Portugal. Lei Complementar 101/2000 - Brasil.

ABSTRACT: This article aims to address the issue of indebtedness of Local Authorities in Portugal, from the Law 73/2013, adopted on July 29, 2013 by Parliament and entered into force from January 1, 2014. In the footsteps of the Master in Law of Local Government, I am attending the University of Minho, it is a relationship and comparison with the Brazilian system, with respect to homeland Law 101/2000. Both laws, among other issues, dealing with the issue of municipal indebtedness cell. The presentation of the possibilities and formats, studying the nuances and its technical and legal aspects, will be the object of this study, along with doctrinal definitions.

Keywords: Financial arrangements of the local authorities. Fiscal Responsibility Law. Law 73/2013 - Portugal. Complementary Law 101/2000 - Brasil. 
SUMÁRIO: Introdução; 1. A necessária boa administração, o controle e a eficiência administrativa; 2. A Lei 73/2013 em Portugal - conhecendo os seus aspectos; 3. A Lei complementar 101/2000 no Brasil - responsabilidade fiscal e um marco regulatório; Considerações finais; Referências.

\section{INTRODUÇÃO}

No intuito de discutir a questão e promover o direito comparado a respeito do tema proposto, primeiro, precisamos equipar, no sentido semântico, os termos, já que mesmo que estejamos abordando sistemas existentes em países que possuem a mesma língua (portuguesa), certo é que este trabalho versa sobre uma legislação que entrou em vigor em Portugal a partir de $1^{\circ}$ de janeiro de 2014, no que tange a sua comparação com o sistema brasileiro, uma lei em vigor há 13 anos e que, portanto, apresenta aspectos práticos relevantes e já aferidos.

Ainda, apesar da lei tratar sobre diversos e diferentes temas relativos as questões de ordem financeira das autarquias locais, o que buscará discutir, aqui, é relativo aos aspectos que dizem respeito ao endividamento das autarquias locais, em Portugal, e dos municípios, quando falamos do Brasil. Aqui, por sinal, reside mais um aspecto de ordem semântica. Enquanto que, em Portugal, Autarquias Locais quer dizer município ou freguesia (enquanto ordem prática existente), no Brasil não há a figura da freguesia, nos limitando, quando falamos da esfera local, a utilizarmos o município, como ente.

Já, na ordem de constituição política do Estado, a de se saber que estamos tratando de um Estado Unitário, como é Portugal, onde o centro de poder é tão somente um e, do Brasil, como uma Federação, em que existem entes federados (União, Estados, Distrito Federal e Municípios, todos detentores de autonomia política, financeira e administrativa).

Feito estes registros, como intuito, há de se discutir em ambos os sistemas, tanto a legislação, como a administração. Ou seja, de nada adianta, tão somente conhecermos a legislação, ou mesmo apenas referi-la, se não a utilizarmos dentro dos conceitos da administração pública ou ainda mais ampliadamente, na gestão da coisa pública.

Os princípios da legalidade, impessoalidade, moralidade, publicidade e eficiência devem, sem dúvida, serem abarcados dentro do marco legal que se espera possa ser observado a partir de ambas as legislações, que impõem limites e regulam os aspectos de ordem financeiras das autarquias locais/municípios.

Assim, teremos como último e melhor resultado, a boa administração pública e o bem comum, com a sociedade sendo a destinatária de melhores serviços, eficiência e práticas de gestão efetivas.

\section{A NECESSÁRIA BOA ADMINISTRAÇÃo, O CONTROLE E A EFICIÊNCIA ADMINISTRATIVA}

A de se ter em conta, que a administração pública necessita de boas práticas, que levem em conta não somente os valores, princípios e normatizações da Carta Magna do país em que está inserida, mas também os aspectos de democracia efetiva e corrente, utilizados como referência.

Um dos aspectos relevantes, evidentemente, dentre tantos outros, está vinculado ao exercício das finanças. 
Rocha, quando estuda a boa-gestão, refere que "o princípio da boa-gestão incorpora uma ideia de prudência nos gastos e apela à mais racional utilização possível das dotações orçamentais." "1

Desta forma, quando falamos em endividamento municipal e na própria autonomia da autarquia local/município, precisamos ter em referência e sempre presente que o financiamento destas não é algo aleatório ou distante, mas advindo da sua própria capacidade de arrecadação ou ainda dos repasses do ente central. Está umbilicalmente vinculado a forma como se administra, utilizando os princípios, a lei e as necessidades reais, capitaneadas pela responsabilidades de quem dirige a administração, em dado momento.

No tema proposto, aparecerão a todo o momento, a conjugação de endividamento municipal e de empréstimo, como primas em uma relação estrutural, não que o endividamento surja tão somente desta, mas como uma situação de própria natureza jurídica, dentro daquilo que nos propomos analisar.

Já quando falamos em manutenção da administração estatal, no nível local, adentrando aos aspectos de ordem prática, lembra Vasques ${ }^{2}$, que, enquanto os impostos, mais associados ao princípio da capacidade contributiva, estavam vinculados a uma organização mais geral e superior de Estado, as taxas, pela sua vinculação com o conhecimento mais real do custo que determinada situação custava, estavam mais vinculados às autarquias locais, pela sua proximidade com o cidadão.

Refere o mesmo autor:

Esta associação das taxas às finanças locais não perdeu actualidade com o terminar do século vinte, bem pelo contrário, veio a ganhá-la por força da tendência recente de transferir poderes tributários da administração central para as comunidades territoriais infra-estaduais, construindo-se assim sistemas tributários marcados pelos princípios da descentralização e da subsidiariedade. ${ }^{3}$

Continuando a sua lição, manifesta que quando há a descentralização do poder financeiro do Estado, automaticamente consegue-se uma maior proximidade e efetividade no atendimento das necessidades dos cidadãos, pois ao se fazer isto, atende-se mais proximamente aquilo que são os seus anseios e consegue identificar, assim como compatibilizar, dentro da ordem e dos aspectos democráticos, as preferências, que não necessariamente são iguais, muito antes pelo contrário, pois, em uma comunidade, normal é que os anseios e as vontades sejam distintas, sofram variações de calibre ou mesmo de sentido. ${ }^{4}$

Esta é a própria referência, quando se fala em administração pública, ou seja, quando da existência da democracia, exercitar o poder, em nome de todos, para que as diferentes vontades e necessidades sociais sejam atendidas, quando existente o interesse público, sem adentrar a aspectos próprios e específicos, que poderiam desvirtuar o sistema. Atende-se aquilo que é o papel de todos atender, mesmo que para alguém, não perfilando-se a uma ideia de que poderia se atender a uma determinada demanda que traga privilégios ou cause um desvirtuamento do efeito que se espera de uma política pública.

Nesta tangente, por certo que atender demandas e administrar, antes de mais nada é assegurar a elaboração, realização e efetivação de políticas públicas, dentro de uma sociedade plural, multifacetada, que diferentes necessidades tem, como já se disse. Para isto, dentro outros aspectos, o ponto relevante da discussão é o financiamento de tais políticas, assim como a sua adequação e existência ao longo do tempo, que podem, de acordo com a maneira com que a

\footnotetext{
${ }^{1}$ ROCHA, Joaquim Freitas da. Direito Financeiro Local (Finanças Locais). Braga: Coimbra, 2009. p. 78

${ }^{2}$ VASQUES, Sérgio. Regime das Taxas Locais: introdução e comentário. Coimbra: Almedina, 2009. p. 12.

${ }^{3}$ VASQUES, Sérgio. Regime das Taxas Locais: introdução e comentário. Coimbra: Almedina, 2009. p. 12.

${ }^{4}$ VASQUES, Sérgio. Regime das Taxas Locais: introdução e comentário. Coimbra: Almedina, 2009. p. 13.
}

Revista de Direito Brasileira | São Paulo, SP | v. 14 | n. 6 | p. 200 - 214 | maio/ago. 2016 
administração age, provocarem reações orçamentais condignas ou mesmo ocasionar dificuldades desta ordem. Um dos pontos que podem determinar a manutenção destas políticas públicas, em dada ordem e necessidade, são os empréstimos. Não só estes, pois como define Rocha:

Em rigor, o crédito público não se subsume às situações de empréstimo, embora não possa deixar de se assinalar que é em relação a elas que assume maior visibilidade. Ainda assim, convém não perder de vista que além da contracção de empréstimos, os sujeitos de Direito público podem utilizar várias outras "formas jurídicas creditícias" como o diferimento de pagamentos, a emissão de obrigações, a concessão de avales ou a instituição de fundos autónomos ou caixas de natureza financeira. ${ }^{5}$

Catarino traz definição que parece oportuna ao debate que estamos inseridos, que seja, os empréstimos públicos e endividamentos:

Os empréstimos públicos podem ter por fim a cobertura de défices orçamentais, de falta na cobrança de impostos, ou a repartição de encargos com as gerações futuras, quando se trate de investimentos públicos cuja utilidade se prolongue no tempo, beneficiando tais gerações vindouras. ${ }^{6}$

No sentido desta lição, poderíamos trazer vários e diferentes exemplos de como poderiam ser definidos critérios e práticas administrativas das autarquias locais/municípios, quando se trata de contrair empréstimos públicos que possam ser utilizados para ações que alcancem o tempo futuro, ou seja, possam não somente beneficiar a geração atual, mas as futuras.

Neste sentido, as obras de infraestrutura parecem bastante apropriadas, pois além de efetivarem, quando prontas, benefícios para a comunidade atual, se prolongam no tempo, por dois diferentes motivos, dentre outros. Um é o da existência da própria infraestrutura (aeroporto, porto, estrada, ferrovia...) e o outro é pela própria capacidade que tem de trazer o desenvolvimento econômico, que gera divisas ao Estado, que por outro lado promove melhorias sociais.

Um porto ou aeroporto, por exemplo, quando existentes, com o embarque e desembarque de mercadorias, geram empregos diretos e indiretos, através de suas ações, tributos são gerados, promovem novos bolsões de desenvolvimento, modificam realidades de municípios e até de regiões/países, sendo que os seus efeitos se prolongam no espaço do tempo, sendo reconhecidos, futuramente, como ações visionárias e efetivamente importantes para o progresso.

Já, outro exemplo que poderia aqui ser referido, é quanto à troca de determinada dívida por outra, quando diminui os encargos e juros daquela primeiramente constituída. Quanto à este exemplo, poderia se citar um caso prático e existente, do Estado do Rio Grande do Sul, no Brasil, que contraiu um grande empréstimo para pagamento de dívida no ano de 1995. Passados quase 15 anos, verificou-se que as somas despendidas mensalmente eram aviltantes, tanto para cobrir as parcelas, como para o pagamento dos juros em si. A solução, ou busca de amenizar os efeitos orçamentários do pagamento da dívida, foi o de contrair novo empréstimo, com índices bem menores de juros, que serviram em sua totalidade para amortizar o empréstimo/dívida antiga. Com isto, buscou-se uma economia mensal considerável, sendo que, estes valores, puderam a ser

\footnotetext{
5 ROCHA, Joaquim Freitas da. Contracção de empréstimos por parte de Municípios (comentário doutrinal ao acórdão do Tribunal de Contas n. ${ }^{\circ} 138 / 2007$ - "caso Oliveira de Azeméis"). Site: http://repositorium.sdum.uminho.pt/browse?type=author\&value=Rocha\%2C+Joaquim+Freitas. Acesso em $15 / 12 / 2013$.

${ }^{6}$ CATARINO, João Ricardo. Finanças Públicas e Direito Financeiro. Coimbra: Almedina, 2012. p. 465. Revista de Direito Brasileira | São Paulo, SP | v. 14 | n. 6 | p. 200 - 214 | maio/ago. 2016
} 
despendidos à outras frentes, como na melhoria de serviços essenciais à população, como saúde, segurança, educação, dentre tantos outros.

Poderíamos trazer outros exemplos, mas talvez estes sejam os mais significativos e que representem aspectos fundamentais quando se traz a possibilidade da contratação de empréstimos que visem a melhorias sociais.

Mais uma vez, o tema e trazido como atual e necessariamente entendido dentro de um novo e moderno contexto social, nas palavras de Catarino:

As profundas modificações econômicas, sociais e políticas sofridas durante todo o século XX determinaram uma radical alteração do comportamento dos Estados, acompanhada por uma dogmática mais propícia ao recurso ao empréstimo como forma de reequilibrar a economia e de estimular o desenvolvimento económico. ${ }^{7}$

Lembra o autor que os Estados se utilizaram de desembolsos exagerados e onerosos, para enfrentarem determinadas situações, que tiveram os seus efeitos horizontalmente divididos ao longo do tempo.

De facto, o financiamento de guerras, o investimento em grandes projetos públicos, como o caminho-de-ferro, ou a necessidade de manter equilibrado os indicadores económicos mais relevantes, tais como a política de emprego, de moeda e da própria taxa de juro, incitaram os Estados a uma intervenção permanente para a qual se requeriam recursos muito mais volumosos de que as receitas tributárias poderiam propiciar num só ano.

A alternativa foi tornar o recurso ao crédito e a assunção de valores de dívida pública muito expressivos como meio de permanente intervenção económica. ${ }^{8}$

Mesmo que o exemplo aqui seja muito mais lato sensu, vale para os casos específicos estudados, das autarquias locais/municípios, pois está a se estudar o endividamento municipal em suas diferentes nuances, seja no seu enquadramento legal, como nos seus próprios geradores. Assim, sejam os pequenos, os médios ou os grandes municípios, em que pese, terem diferentes realidades, assim como os de mesmo nível em Portugal ou no Brasil, até pelas características relacionadas as competências de cada Estado, podem estarem abarcados pelos exemplos em maior, ou menor nível. Ou ainda, pode ser apenas exemplificativo.

O que importa ressaltar, ainda, são as práticas administrativas adotadas pelos mandatários. Ou seja, a administração pública contrai determinado empréstimo, tornando-a dívida, por algum motivo, que tem à frente alguém, um administrador/gerente, que toma a decisão, que deve ser baseada em aspectos técnicos, econômicos, e sim, também políticos, na bom e uníssono sentido da palavra.

Para isto, há de se clarificar que existe a necessidade de estarem aqui perfectibilizados todas as essências inerentes à própria democracia, como a lei, os princípios constitucionais e além de tudo, a observância de uma característica elementar que é a do interesse público e a ponderação dos efeitos da medida adotada. Não se pode retirar daqui, também, a necessária discussão pública, entre os entes, os Poderes e a sociedade, para uma justa e equilibrada decisão fruto de um consenso, ou pelo menos da maioria, já que os efeitos serão percebidos e repartidos entre todos, sejam aqueles positivos, ou muito especialmente os negativos.

Outro ponto que deve aparecer translúcido, aqui, é a transparência do ato, a ser controlado pelos órgãos de controle, os internos e externos, como própria condição jurídica do ato proposto e executado.

${ }^{7}$ CATARINO, João Ricardo. Finanças Públicas e Direito Financeiro. Coimbra: Almedina, 2012. p. 466.

${ }^{8}$ CATARINO, João Ricardo. Finanças Públicas e Direito Financeiro. Coimbra: Almedina, 2012. p. 466.

Revista de Direito Brasileira | São Paulo, SP | v. 14 | n. 6 | p. 200 - 214 | maio/ago. 2016 
Se existe o interesse público, gerido dentro da boa administração pública e os seus mais elevados princípios, designados pelo ambiente democrático e pela observância dos princípios em sua perfectibilização prática, há de se preceituar que a gestão pública acontece e ocorre.

Até porque, ao fim e ao cabo, o que importa nesta discussão e nestes componentes expressados são os resultados sociais, no atendimento das políticas públicas eficazes, que diminuam as desigualdades sociais, promovam o desenvolvimento, em um ambiente onde todos os cidadãos se sintam pertencentes a uma comunidade, dos seus valores e desígnios.

\section{A LEI 73/2013 EM PORTUGAL - CONHECENDO OS SEUS ASPECTOS}

Primeiramente, quanto aos aspectos normativos das autarquias locais, lição de Rocha, nos posiciona sobre o arcabouço legal, que determina a posição ocupada por esta, no conjunto normativo do Estado, quando fala-se no poder regulamentar que a autarquia local detém, como expresso pela Constituição de Portugal $^{9}$ :

Os poderes regulamentares das Autarquias Locais - manifestação da denominada "administração descentralizada" - devem ser enquadrados no contexto mais vasto do especial estatuto de autonomia que constitucionalmente lhes é reconhecido. No âmago de tal estatuto ganha particular relevo a autonomia normativa, significativa da ideia de que as Autarquias dispõem de poderes no sentido de emanar verdadeiras normas jurídicas, autênticos padrões de comportamento, sob a forma de regulamentos, embora localmente circunscritos e determinados. ${ }^{10}$

Rocha, em sua obra, ainda aborda a importância de tal autonomia, como forma de delimitar a própria atuação do Estado:

A autonomia referida deve ser aqui especialmente destacada pois é ela que, no fundo, vai impedir o Estado maior de se imuscuir nos assuntos locais e impossibilitar a lei de se substituir ao regulamento local na regulamentação específica de questões locais. Esta reserva de regramento local deve mesmo ser encarada como uma garantia institucional que tem as Autarquias como titulares. ${ }^{11}$

Assim, como pode ser visto, as autarquias locais em Portugal são dotadas de autonomia, sendo que esta as leva a tomar decisões dentro da sua jurisdição. Decisões estas que as levam a consequências, objeto do próprio ato de governar e decidir caminhos a serem trilhados.

Um deles pode ser, como consequência, dentre tantas possibilidades e situações, o tema proposto e um dos elencados pela lei discutida, o do endividamento municipal.

Parece que na atualidade falarmos de endividamento municipal, ou no seu amplo aspecto, como um endividamento do próprio Estado, não é possível, quando refletimos o modelo português, sem nos conectarmos à União Europeia, seus marcos legais e os tratados de todas as ordens que conectam Estados em obediência a regras únicas e centralizadas.

Neste sentido, as próprias modelagens legislativas tem sido uniformizadas ou aproximadas, a partir de conceitos e necessidades de partilhas comuns de modelos de Estado. A

\footnotetext{
9 Artigo 241 da Constituição de Portugal: As autarquias locais dispõem de poder regulamentar próprio nos limites da Constituição, das leis e dos regulamentos emanados das autarquias de grau superior ou das autoridades com poder tutelar.

${ }^{10}$ ROCHA, Joaquim Freitas da. Constituição, Ordenamento e Conflitos Normativos - Esboço de uma Teoria Analítica da Ordenação Normativa. Coimbra: Coimbra, 2008. p. 705.

${ }^{11}$ ROCHA, Joaquim Freitas da. Constituição, Ordenamento e Conflitos Normativos - Esboço de uma Teoria Analítica da Ordenação Normativa. Coimbra: Coimbra, 2008. p. 705.
}

Revista de Direito Brasileira | São Paulo, SP | v. 14 | n. 6 | p. 200 - 214 | maio/ago. 2016 
própria Carta Europeia de Autonomia Local, ratificada por Portugal no ano de 1990, trata do tema com por menoridades.

Desta forma, necessária sempre observar o tema não da forma individualizada de um Estado, mas dentro de um contexto mais amplo e relativizado, preservando a autonomia, mas contendo características que podem se dar a partir de determinado modelo.

No que tange os aspectos de orçamento e endividamento municipal, um dos princípios que necessita observância é a equidade intergeracional, sendo, nas palavras de Catarino:

As questões relativas à transferência de responsabilidade entre gerações são da maior importância. Referimo-nos a elas quanto tratamos da regra orçamental da equidade intergeracional, prevista de forma expressa no artigo $10^{a}$ da LEO. São, de facto, preocupantes os níveis de gasto de recursos e a diferença entre a capacidade de produção de riqueza e de dispêndio da atual geração. A nova regra da equidade intergeracional expressa esta crescente preocupação com os défices excessivos, com o impacto que tem nas contas do Estado, na sua capacidade de endividamento, na qualidade do crédito externo, na solvabilidade das responsabilidades financeiras e nas pressões inflacionistas.

Esta realidade levanta problemas de ordem ética, pela evidente responsabilização das gerações futuras por níveis de bem-estar desejados pela geração presente. Questiona-se também qual deva ser o nível ótimo do limite dos níveis de bem-estar em função da capacidade para produzir riqueza de cada geração. ${ }^{12}$

A Lei 73/2013 faz referência a este princípio da equidade geracional, que na nossa ótica tem toda a relação com o tema, já que é a busca da garantia de um equilíbrio dos custos, gastos, benefícios e investimentos das administrações ao longo das gerações.

Neste sentido, o artigo $9^{\circ}$ da Lei fala que "a atividade financeira das autarquias locais está subordinada ao princípio da equidade na distribuição de benefícios e custos entre gerações, de modo a não onerar excessivamente as gerações futuras (...)"

Necessário utilizarmos duas definições que são importantes no bojo de nossa pesquisa, que são empréstimo público e dívida pública. Segundo Sousa Franco, a dívida pública é o "conjunto das situações passivas que resultam para o Estado do recurso ao crédito público"13. Já o empréstimo público "é um acto pelo qual o Estado beneficia de uma transferência de meios de liquidez, constituindo-se na ulterior obrigação de os reembolsar e/ou pagar juros"14.

A Lei 73/2013, que "estabelece o regime financeiro das autarquias locais e das entidades intermunicipais", traz o tema do endividamento municipal nos seus artigos $48^{\circ}$ ao $67^{\circ}$.

Os princípios que orientam o regime de crédito e de endividamento municipal aparecem no primeiro artigo do tema, o $48^{\circ}$, enaltecendo os princípios da estabilidade dos orçamentos, da solidariedade recíproca, e o da equidade intergeracional, já referido aqui. Além destes, ainda são princípios basilares a serem observados neste tema, o do rigor e da eficiência, por exemplo.

$\mathrm{O}$ artigo $49^{\circ}$ elenca o regime de crédito dos municípios, importando referir que os de curto prazo tem o período de um ano e os de médio e longo prazo superiores a este um ano (número 2). O número 5 do mesmo artigo traz importante consideração, que seja, os empréstimos podem ser contraídos, desde que autorizados pela Assembleia Municipal. Para que isto ocorra, o pedido de autorização de empréstimo pela autarquia municipal deve estar acompanhado das condições do negócio, com a proposta de pelo menos três instituição que tenham autorização por lei a concederem crédito. Ainda, deverá ser demonstrado à Assembleia Municipal, a capacidade de endividamento do município. Se o contrato de empréstimo for de médio e longo prazo, se

${ }^{12}$ CATARINO, João Ricardo. Finanças Públicas e Direito Financeiro. Coimbra: Almedina, 2012. p. 480.

${ }^{13}$ SOUSA FRANCO, António L. Finanças Públicas e Direito Financeiro. Volume I e II. 4. ed. Coimbra: Almedina, 2012. p. 87.

${ }^{14}$ SOUSA FRANCO, António L. Finanças Públicas e Direito Financeiro. Volume I e II. 4. ed. Coimbra: Almedina, 2012. p. 91. Revista de Direito Brasileira | São Paulo, SP | v. 14 | n. 6 | p. 200 - 214 | maio/ago. 2016 
mantendo ao longo de dois ou mais mandatos, deverão ser aprovados pro maioria absoluta dos membros da Assembleia (número 7 da lei).

$\mathrm{O}$ artigo $50^{\circ}$ da lei estabelece que os empréstimos de curto prazo são efetivados tão somente para saldar dificuldades de tesouraria, necessitando que sejam cumpridos até o final do exercício econômico em que foram contratados.

Segundo a lição de Rocha, "aqueles que se esgotam no próprio ano financeiro em que são contraídos -, o legislador não deixa margem para dúvidas: eles apenas podem ser contraídos "para ocorrer dificuldades de tesouraria". 15

Prossegue o seu raciocínio, o mesmo autor, dizendo que: "são situações nas quais se verifica um desencontro momentâneo entre a entrada de receitas e a efectivação das despesas". ${ }^{16}$

Os empréstimos de médio e longo prazo podem ser efetivados para a realização de investimentos ou para a utilização na recuperação financeira municipal (artigo $51^{\circ}$ ). Os prazos para estes empréstimos não podem exceder a vida útil do investimento e nem ultrapassarem o prazo de 20 anos.

Segundo Rocha, em qualquer das situações elencadas pela lei podem "os municípios recorrer à contratação de empréstimos, sendo, no entanto, diferentes os procedimentos a adoptar os constrangimentos financeiros impostos e as consequências de incumprimento." ${ }^{\prime 17}$

Outro ponto que merece destaque é quanto ao limite da dívida do município, sendo este explicitado no artigo $52^{\circ}$, estabelecendo que "a dívida total de operações orçamentais do município, incluindo a das entidades previstas no artigo $54^{\circ}$, não pode ultrapassar, em 31 de dezembro de cada ano, 1,5 vezes a média da receita corrente líquida cobrada nos três exercícios anteriores". Neste tocante vale lembrar que o artigo $54^{\circ}$ elenca as seguintes entidades, que estão englobadas quando falamos em município e dívida: serviços municipalizados e intermunicipalizados, entidades intermunicipais e associativas municipais, as empresas locais, as cooperativas e as fundações e as entidades de outra natureza, quando havendo controle e participação do município. Importante ressaltar que o grau/percentual de responsabilidade/participação do município em uma destas entidades, será o balizador do percentual comprometido no cálculo. (Artigo 54\%, I, letras $a$ até $e$ ).

O regime de crédito e as regras de endividamento das freguesias estão estabelecidos no artigo $55^{\circ}$ da lei. Como esta figura da organização política não existe no regramento brasileiro, não a explicitaremos, tão somente nomeando a sua localização na referida lei, para necessidade de consulta ou interesse.

Um dos itens importantes da lei são os mecanismos de alerta precoce e de recuperação financeira municipal, aparecendo no artigo $56^{\circ}$ o alerta precoce de desvios, que diz:

1 - Sempre que, na informação reportada à DGAL, a dívida total prevista no artigo 52..$^{\circ}$ atinja ou ultrapasse a média da receita corrente liquida cobrada nos três exercícios anteriores, são informados os membros do Governo responsáveis pelas áreas das finanças e das autarquias locais, bem como os presidentes dos órgãos executivo e deliberativo do município em causa, que informam os respetivos membros na primeira reunião ou sessão seguinte. 2 - Sempre que, na informação reportada à DGAL, a dívida total prevista no artigo 52. ${ }^{\circ}$ atinja ou ultrapasse 1,5 vezes a média da receita corrente líquida cobrada nos três exercícios anteriores, são informadas as entidades referidas no número anterior, bem como o Banco de Portugal. 3 - No caso de o município registar durante dois anos consecutivos uma taxa de execução da receita prevista no orçamento respetivo inferior a $85 \%$ são informadas

${ }^{15}$ ROCHA, Joaquim Freitas da. Direito Financeiro Local (Finanças Locais). Braga: Coimbra, 2009. p. 153.

${ }^{16}$ ROCHA, Joaquim Freitas da. Direito Financeiro Local (Finanças Locais). Braga: Coimbra, 2009. p. 153.

${ }^{17}$ ROCHA, Joaquim Freitas da. Direito Financeiro Local (Finanças Locais). Braga: Coimbra, 2009. p. 155. Revista de Direito Brasileira | São Paulo, SP | v. 14 | n. 6 | p. 200 - 214 | maio/ago. 2016 
as entidades referidas no $n .^{\circ} \quad 1$. 4 - O alerta referido nos números anteriores é emitido pela DGAL, no prazo de 15 dias, a contar da data limite do reporte de informação constante do artigo 78.. 5 - Os alertas referidos nos n.os 1 e 2 incluem ainda a evolução do rácio referido no n. ${ }^{\circ} 1$ ao longo dos três exercícios anteriores.

Os municípios que ultrapassarem os limites de dívida estabelecidos no artigo $52^{\circ}$ (em 31 de dezembro de cada ano, 1,5 vezes a média da receita corrente líquida cobrada nos três exercícios anteriores), recorrerão a dois distintos modelos de recuperação financeira, a saber: (artigo $57^{\circ}$ ) a) saneamento financeiro e b) recuperação financeira.

O primeiro, saneamento financeiro, está elencado entre os artigos $58^{\circ}$ e $60^{\circ}$ da lei, importando ressaltar alguns aspectos relevantes. O primeiro deles vem elencado no artigo $58^{\circ}$ (I, $a$ e $b$ ), número estabelece o momento em que é considerada a necessidade de contração de empréstimo para o saneamento, com o intuito, nas palavras da lei "tendo em vista a reprogramação da dívida e a consolidação de passivos financeiros". Isto se dará quando, ao final do exercício, a dívida ultrapassar o limite enumerado no artigo $52^{\circ}$ da mesma lei, ou ainda, quando "o montante da dívida, excluindo empréstimos, seja superior a 0,75 vezes a média da receita corrente líquida cobrada nos três exercícios anteriores."

Sobre o saneamento financeiro, Rocha assevera que: "os empréstimos contraídos com a finalidade de saneamento financeiro pressupõem uma situação de desequilíbrio financeiro conjuntural." 18

Vejamos o que nos diz o número 3 do artigo 58 da lei:

2 - Caso a dívida total prevista no artigo 52. ${ }^{\circ}$ se situe entre 2,25 e 3 vezes a média da receita corrente líquida cobrada nos três exercícios anteriores, o município é obrigado a contrair um empréstimo para saneamento financeiro ou a aderir ao procedimento de recuperação financeira previsto nos artigos $61 .^{\circ} \mathrm{e}$ seguintes.

Neste ponto merece destaque, quando é referido que, nos primeiros casos (artigo 58 $, \mathrm{I}, a$ e $b$ ), citados anteriormente, o município deve contrair empréstimo, enquanto que neste último caso (artigo 58 $8^{\circ}$ número 3), o município é obrigado a fazê-lo.

Outro aspecto que deve ser considerado é o enunciado pelo número 4 do mesmo artigo, referindo este de que o resultado das operações de empréstimo não pode fazer com que haja um aumento da dívida total do município.

Há a necessidade de fundamentação para os pedidos de empréstimos quando requeridos para o saneamento municipal, demonstrando a sua situação financeira e um plano para o período em que se operar (número 5, artigo 58\%). O número 6 estabelece que: "os empréstimos para saneamento financeiro tem um prazo máximo de 14 anos e um período máximo de carência de um ano".

$\mathrm{O}$ artigo $59^{\circ}$ da lei, traz considerações referentes ao plano de saneamento, como a programação e os objetivos do mesmo, ou seja, quais os ajustes e as medidas adotadas pelo município, tanto para a concessão do empréstimo, como também para os efeitos esperados para a recuperação da situação financeira do município. Aqui, uma verdadeira rigidez orçamentária, com elevação dos preceitos constitucionais e principio lógicos da perseguição de um orçamento equilibrado, redução das despesas e maximização das receitas. $\mathrm{O}$ plano de saneamento tem por fim a redução da dívida aos níveis estabelecidos no artigo $52^{\circ}$.

${ }^{18}$ ROCHA, Joaquim Freitas da. Direito Financeiro Local (Finanças Locais). Braga: Coimbra, 2009. p. 156. 
Neste artigo $59^{\circ}$, vale referir, ainda que:

5 - Durante o período do empréstimo o município fica obrigado a: a)Cumprir o plano de saneamento financeiro; b)Não celebrar novos empréstimos de saneamento financeiro; c)Remeter à DGAL os relatórios semestrais sobre a execução do plano de saneamento, no prazo máximo de 30 dias, a contar do final do semestre a que reportam.

Quanto à possibilidade de incumprimento do plano de saneamento, as penalidades que o município sofrerá estão elencadas no artigo 60 da lei, importando referir que, como efeito, serão retidas as transferências a que o município teria direito, por parte do Estado e transferidas à Instituição Financeira ou aos credores do município (número 1 do artigo). Antes da retenção, haverá a oitiva do município e o seu "limite máximo $20 \%$ do respetivo duodécimo, das transferências do Orçamento do Estado não consignadas”. (número 2 do artigo).

Já, o segundo, a recuperação financeira municipal, está descrita no artigos $61^{\circ}$ à $64^{\circ}$ da lei e tem como conceito a ruptura financeira.

Quanto à este, Rocha declara que "são situações de extrema gravidade no âmbito das quais o défice orçamental - excedente das despesas sobre as receitas - se apresenta recorrente e as possibilidades de sanar são dificilmente vislumbráveis no imediato." "19

Estas situações são evidenciadas "sempre que a dívida total prevista no artigo $52^{\circ}$ seja superior, em 31 de dezembro de cada ano, a 3 vezes a média da receita corrente líquida cobrada nos últimos três exercícios". (número 3 do artigo $61^{\circ}$ )

A assistência aos municípios nesta situação se dará pelo FAM - Fundo de Apoio Municipal, uma pessoa coletiva de direito público, que será dotada de autonomia administrativa e financeira. (artigo $61^{\circ}, 62^{\circ}, 63^{\circ}$ da lei)

Neste caso, a lei está a buscar uma entidade dotada de certas características e que possa atuar no apoio a municípios que se encontram numa situação crítica e de ruptura do seu meio financeiro, sendo evidentemente, por estas características, um processo de ordem morosa e especifica, necessitando para isto, de um cuidado também desta ordem. artigo $65^{\circ}$ :

Os artigos $65^{\circ}, 66^{\circ}$ e $67^{\circ}$ trazem o Fundo de Regularização Fiscal - FRM, a saber no

1 - O FRM é constituído pelos montantes das transferências orçamentais deduzidas aos municípios, sendo utilizado para, através da DGAL, proceder ao pagamento das dívidas a terceiros do município respetivo. 2 - Para efeitos do disposto no número anterior, são incluídas no FRM todas e quaisquer verbas que resultem de retenções nas transferências orçamentais, nomeadamente as retidas ao abrigo do $\mathrm{n}^{\circ} 2$ do artigo $60 .^{\circ}$, salvo disposição legal em contrário.

3 - O montante pago nos termos do número anterior não contribui para a redução a que se refere a alínea a) do.$^{\circ} 3$ do artigo $52 .^{\circ}$.

Neste estudo, da lei 73/2013, pode-se identificar claramente a perseguição do rigorismo fiscal, da responsabilidade da gestão e dos princípios da legalidade, impessoalidade, transparência, moralidade, publicidade e outros, contidos dentro das características de boa gestão e eficiência administrativa. Neste quesito, vale salientar, que a nova lei nada mais é do que a adequação natural dos tempos, da necessária modernização da legislação, a partir dos fatos e da realidade vivida em determinado Estado. Assim faz Portugal, e bem, para que como resultado

${ }^{19}$ ROCHA, Joaquim Freitas da. Direito Financeiro Local (Finanças Locais). Braga: Coimbra, 2009. p. 158. Revista de Direito Brasileira | São Paulo, SP | v. 14 | n. 6 | p. 200 - 214 | maio/ago. 2016 
haja uma avanço na seriedade com que se administra um município, impondo limites, mostrando caminhos e definindo soluções.

Para tanto, Governo, Autarquias, Órgãos de Controle, Poderes Executivo e Judiciário, se somam neste esforço.

\section{A LEI COMPLEMENTAR 101/2000 NO BRASIL - RESPONSABILIDADE FISCAL E UM MARCO REGULATÓRIO}

A Lei Complementar 101/2000, chamada Lei de Responsabilidade Fiscal, em vigência já há 13 anos, pode ser considerado um dos marcos legais importantes no contexto pós-Constituição de 1988, Carta esta que estabeleceu o município como ente da federação e o dotou de autonomia política, econômica e administrativa.

Passados mais de uma década, esta análise pode ser considerada quase que um consenso dentro dos aspectos que norteiam a administração pública, pois com a edição desta legislação, fez-se uma transmutação institucional e também de certa forma no aspecto de ordem cultural no que diz respeito às finanças públicas. Isto porque a legislação trouxe a restrição orçamentária, que no seu bojo, representa seriedade e responsabilidade com o trato da coisa pública.

A Lei de Responsabilidade Fiscal nada mais é do que a normatização da responsabilidade na gestão fiscal, a partir da ação de determinado governo, nos três níveis federados: União, Distrito Federal, Estados e Municípios.

Aqui pode também ser utilizada a questão do controle da ação do governo. Assim, a norma que estamos estudando, fica tangenciada aos requisitos impostos pelos princípios da legalidade, impessoalidade, moralidade, eficiência, publicidade, que estão descritos no artigo 37 da Carta brasileira ${ }^{20}$. Neste sentido, a lição de Di Pietro:

A finalidade do controle é assegurar que a Administração atue em consonância com os princípios que lhe são impostos pelo ordenamento jurídico, como os da legalidade, moralidade, finalidade pública, publicidade, motivação, impessoalidade; em determinadas circunstâncias, abrange também o chamado controle de mérito e que diz respeito aos aspectos discricionários da atuação administrativa. ${ }^{21}$

Também, há de se lembrar os tipos de controle que podem ser exercidos, o que é esclarecido por Meirelles:

Os tipos e formas de controle da atividade administrativa variam segundo o Poder, órgão ou autoridade que o exercita ou o fundamento, o modo e o momento de sua efetivação. Assim, temos a considerar com precedência sobre os demais, por sua permanência e amplitude, o controle da própria Administração sobre seus atos e agentes (controle administrativo ou executivo) e, a seguir, o do Legislativo sobre determinados atos e agentes do Executivo (controle legislativo ou parlamentar) e, finalmente, a correção dos atos ilegais de qualquer dos Poderes pelo Judiciário. ${ }^{22}$

A Lei de Responsabilidade Fiscal brasileira é destinada aos entes estatais (União, Estados, Distrito Federal e Municípios), abrangendo os três poderes (Executivo, Legislativo,

\footnotetext{
${ }^{20}$ Constituição Federal brasileira - Artigo 37: A administração pública direta e indireta de qualquer dos Poderes da União, dos Estados, do Distrito Federal e dos Municípios obedecerá aos princípios de legalidade, impessoalidade, moralidade, publicidade e eficiência (...).

${ }^{21}$ DI PIETRO, Maria Sylvia Zanella. Direito Administrativo. Rio de Janeiro. 12a ed. Atlas, 2006. P. 575.

${ }^{22}$ MEIRELLES, Hely Lopes. Direito Administrativo Brasileiro. $32^{\mathrm{a}}$ ed. São Paulo: Malheiros, 2006. p. 569. Revista de Direito Brasileira | São Paulo, SP | v. 14 | n. 6 | p. 200 - 214 | maio/ago. 2016
} 
Judiciário), além do Ministério Público e dos Tribunais de Contas. Toda a administração direta, fundos, autarquias, fundações e empresas estatais estão sob a égide da lei.

Feito estes registros necessários, focar-se-á nos aspectos relativos aos municípios e as regras de endividamento, no intuito proposto por este trabalho.

As regras relativas a dívida e endividamento, em específico, estão enumeradas entre o artigo 29 e 42 da Lei.

Segundo o artigo 30 da Lei e por regulamentação do Senado Federal brasileiro, a dívida consolidada (aquela considerada de longo prazo, com vigência superior a 12 meses), deve obedecer os limites que foram fixados, sendo de 1,2 vezes a receita corrente líquida (RCL) para os municípios e de 2 vezes a Receita Corrente Líquida para os Estados e para o Distrito Federal.

Neste sentido, ainda, há a recomendação da lei para que os gestores públicos verifiquem, ao final de cada quadrimestre, se a dívida consolidada atende ao limite expresso, isto como forma de monitoramento e para que as medidas necessárias possam ser estabelecidas e cumpridas.

Ressalta-se, ainda, que os precatórios judiciais que porventura não foram pagos no orçamento, devam ser incluídos na dívida consolidada.

$\mathrm{O}$ artigo 31 da lei expressa que se a dívida consolidada de um ente federativo ultrapassar o limite estabelecido ao final do quadrimestre, deve o ente reposicioná-la ao nível legal, nos três subsequentes, reduzido o excesso em pelo menos $25 \%$ no primeiro. Aqui, o que importa, são as penalidades impostas ao ente federado, que enquanto perdurar o excesso, estará proibido de realizar operação e crédito. Importa, ainda, neste artigo da lei, mencionar:

$\S 2^{\underline{o}}$ Vencido o prazo para retorno da dívida ao limite, e enquanto perdurar o excesso, o ente ficará também impedido de receber transferências voluntárias da União ou do Estado.

$\S 3^{\circ}$ As restrições do $\S 1^{\circ}$ aplicam-se imediatamente se o montante da dívida exceder o limite no primeiro quadrimestre do último ano do mandato do Chefe do Poder Executivo.

$\S 4^{\circ} \mathrm{O}$ Ministério da Fazenda divulgará, mensalmente, a relação dos entes que tenham ultrapassado os limites das dívidas consolidada e mobiliária. ${ }^{23}$

A lei brasileira também impõe vedações a realizações de operações de crédito, estando as mesmas descritas entre o artigo 34 e 37 da lei.

$\mathrm{O}$ artigo 35 vale referir, pois mesmo que parágrafos e artigos seguintes pormenorizem as regras contidas neste, o artigo serve como um parâmetro a ser seguido pela Administração Pública, que seja, impede que haja realização de operação de crédito entre entes da Federação.

Art. 35. É vedada a realização de operação de crédito entre um ente da Federação, diretamente ou por intermédio de fundo, autarquia, fundação ou empresa estatal dependente, e outro, inclusive suas entidades da administração indireta, ainda que sob a forma de novação, refinanciamento ou postergação de dívida contraída anteriormente.

O que o artigo e seus componentes pretendem, como resultado, é que haja a restrição de forma exclusiva aos órgãos financeiros para a realização das operações de crédito. Desta forma, há a facilitação do controle por parte do Banco Central, das operações de ordem financeira.

Neste sentido, há mesma restrição na lei Portuguesa.

\footnotetext{
${ }^{23} \mathrm{http}: / /$ www.planalto.gov.br/ccivil_03/leis/lcp/lcp101.htm. Acesso em 13/12/2013.

Revista de Direito Brasileira | São Paulo, SP | v. 14 | n. 6 | p. 200 - 214 | maio/ago. 2016
} 
Importante trazer aqui o artigo 52 da Constituição Federal brasileira, que determina competência exclusiva ao Senado Federal para os assuntos relativos as operações financeiras dos entes federados:

Art. 52. Compete privativamente ao Senado Federal:

(...)

V - autorizar operações externas de natureza financeira, de interesse da União, dos Estados, do Distrito Federal, dos Territórios e dos Municípios;

VI - fixar, por proposta do Presidente da República, limites globais para o montante da dívida consolidada da União, dos Estados, do Distrito Federal e dos Municípios;

VII - dispor sobre limites globais e condições para as operações de crédito externo e interno da União, dos Estados, do Distrito Federal e dos Municípios, de suas autarquias e demais entidades controladas pelo Poder Público federal;

VIII - dispor sobre limites e condições para a concessão de garantia da União em operações de crédito externo e interno;

IX - estabelecer limites globais e condições para o montante da dívida mobiliária dos Estados, do Distrito Federal e dos Municípios (... $)^{24}$

Ressalta-se ainda, que as operações financeiras permitidas pela lei se dão em caráter bastante restrito, pois não podem financiar, direta ou indiretamente as despesas correntes e nem as dívidas que porventura tenham sido contraídas junto à própria instituição.

Ainda há as Operações de Crédito por Antecipação de Receita Orçamentária (ARO), especificadas no artigo $38 \mathrm{da} \mathrm{Lei}^{25}$, mas sujeita a diversas restrições, principalmente no último ano do mandato do Prefeito, quando não é permitida.

Um dos grandes avanços da Lei é quanto os restos a pagar, elencados no artigo 42:

É vedado ao titular de Poder ou órgão referido no art. 20, nos últimos dois quadrimestres do seu mandato, contrair obrigação de despesa que não possa ser cumprida integralmente dentro dele, ou que tenha parcelas a serem pagas no exercício seguinte sem que haja suficiente disponibilidade de caixa para este efeito.

Parágrafo único. Na determinação da disponibilidade de caixa serão considerados os encargos e despesas compromissadas a pagar até o final do exercício.

\footnotetext{
${ }^{24}$ http://www.planalto.gov.br/ccivil_03/constituicao/constituicaocompilado.htm. Acesso em 13/12/2013.

${ }^{25}$ Art. 38. A operação de crédito por antecipação de receita destina-se a atender insuficiência de caixa durante o exercício financeiro e cumprirá as exigências mencionadas no art. 32 e mais as seguintes:

I - realizar-se-á somente a partir do décimo dia do início do exercício;

II - deverá ser liquidada, com juros e outros encargos incidentes, até o dia dez de dezembro de cada ano;

III - não será autorizada se forem cobrados outros encargos que não a taxa de juros da operação, obrigatoriamente prefixada ou indexada à taxa básica financeira, ou à que vier a esta substituir;

IV - estará proibida:

a) enquanto existir operação anterior da mesma natureza não integralmente resgatada;

b) no último ano de mandato do Presidente, Governador ou Prefeito Municipal.

$\S 1^{\circ}$ As operações de que trata este artigo não serão computadas para efeito do que dispõe o inciso III do art. 167 da Constituição, desde que liquidadas no prazo definido no inciso II do caput.

$\S 2^{\underline{0}}$ As operações de crédito por antecipação de receita realizadas por Estados ou Municípios serão efetuadas mediante abertura de crédito junto à instituição financeira vencedora em processo competitivo eletrônico promovido pelo Banco Central do Brasil.

§ 3oㅡ Banco Central do Brasil manterá sistema de acompanhamento e controle do saldo do crédito aberto e, no caso de inobservância dos limites, aplicará as sanções cabíveis à instituição credora.
}

Revista de Direito Brasileira | São Paulo, SP | v. 14 | n. 6 | p. 200 - 214 | maio/ago. 2016 
O objetivo proposto neste artigo é o de evitar que seja contraída dívida flutuante, elevando nestes quesitos os aspectos de ordem política. Ou seja, no Brasil, em que o cargo de Prefeito tem mandato de 4 anos, prevista uma possibilidade de reeleição, a lei tenta frear possíveis excessos cometidos, face ao período eleitoral, que possam trazer prejuízos à administração do município.

A Lei de Responsabilidade Fiscal, propôs e tem alcançado, passados 13 anos de sua vigência, uma nova matriz programática dentro da Administração Pública, muito especialmente na esfera dos municípios. Um gerenciamento financeiro adequado, com o devido controle legal e com normativas que põem e especificam bases a serem seguidas pelos administradores. A discricionariedade perde terreno, ganhando corpo o determinismo e a seriedade com que o dinheiro público deve ter, sendo público e não ao prazer e satisfação apenas de quem decide, mas para quem decide.

Em que pese não haver relação com o tema proposto, além destes quesitos todos citados, que se referem ao endividamento municipal, ainda, a Lei de Responsabilidade Fiscal trouxe a busca, através de seus preceitos, o equilíbrio entre as receitas e as despesas, o estabelecimento de metas a serem cumpridas e perseguidas.

Outro ponto que merece grande destaque são os limites impostos à Administração Pública, no que tange ao gasto com pessoal, havendo penalidades, para quem não o cumprir, podendo haver dispensas, inclusive, se necessário. A lei prevê também os percentuais máximos a serem gastos com os Poderes nas três esferas federadas, as despesas com a seguridade social, os limites e formas de concessão de incentivos fiscais. A transparência da gestão dos recursos públicos também está inserida na lei, prevendo que todos os atos e documentos sejam disponibilizados e demonstrados através de meios eletrônicos de acesso público.

Todas as temáticas inseridas na lei estarão submetidas e serão avaliadas pelos órgãos de controle, sejam os internos ou externos.

\section{CONSIDERAÇÕES FINAIS}

O objetivo deste artigo foi o de elencar algumas bases, mesmo que bastante apertadas, quanto aos aspetos das autarquias/municípios e as possibilidades e existências de endividamento.

No que tange a isto, demonstrou-se duas legislações. Uma, a brasileira, em vigência já há 13 anos, através da lei complementar 101/2000 e a outra, em Portugal, iniciada a sua vigência em 01 de janeiro de 2014, a lei 73/2013.

A lei brasileira, já pode entender-se como uma lei madura, que pode ser analisada em seus amplos aspectos, sejam aqueles vinculados aos próprios princípios da administração pública, sejam os relativos ao próprio controle desta. Mas, desta lei, podemos, e muito, trazer a sua relevância quanto a uma mudança de cultura no próprio ato de administrar, buscando uma eficiência e um determinismo gerencial, que fazem com que os valores de uma boa gestão pública ganhem significativo espaço dentro da esfera de poder local, a saber, os municípios brasileiros.

No que se refere à lei Portuguesa, ainda que no encalço de uma nova legislação, trata-se já, de um aprimoramento da ordem legal, dentro de novos compassos e modelos, a serem buscados com novos e modernos comprometimentos que tão somente a prática fornecerá elementos de avaliação, futuramente.

O certo é que os objetivos elencados em ambas as legislações sãos os mesmos, não os de ordem técnica, que variam, como já vimos, mas aqueles que são os ditos para uma administração mais vinculada, séria, combativa e eficiente. 
Na realidade, busca-se um comprometimento cada vez maior entre o equilíbrio do que se arrecada e o que se gasta, como um conceito normativo de valor de toda a sociedade, que é a última pagadora e credora, do bem ou do mal que ações e decisões podem gerar.

A síntese é que somente pode se gastar o que se tem, como em uma família, ou em uma casa, e as decisões, tomadas por todos, terão como prejudicados ou beneficiados, sempre o mesmo grupo. Vinculação esta que não pode deixar de estar alinhada aos próprios conceitos democráticos, de decisão e participação da sociedade.

Neste sentido, conclui-se que as legislações sobre endividamento municipal fornecem amplo parâmetro legal a ser perseguido, oferecendo ferramentas de apoio e de controle, visando tão somente o bem comum das comunidades a ela vinculadas.

\section{REFERÊNCIAS}

CATARINO, João Ricardo. Finanças Públicas e Direito Financeiro. Coimbra: Almedina, 2012.

DI PIETRO, Maria Sylvia Zanella. Direito Administrativo. Rio de Janeiro. 12a ed. Atlas, 2006.

MEIRELLES, Hely Lopes. Direito Administrativo Brasileiro. 32a ed. São Paulo: Malheiros, 2006.

NOGUEIRA, João Félix Pinto. Direito Fiscal Europeu - O Paradigma da Proporcionalidade. Coimbra: Coimbra, 2010.

ROCHA, Joaquim Freitas da. Constituição, Ordenamento e Conflitos Normativos - Esboço de uma Teoria Analítica da Ordenação Normativa. Coimbra: Coimbra, 2008.

. Direito Financeiro Local (Finanças Locais). Braga: Coimbra, 2009.

. Contracção de empréstimos por parte de Municípios (comentário doutrinal ao acórdão do Tribunal de Contas n. ${ }^{\circ} 138 / 2007$ - “caso Oliveira de Azeméis”). Site: $\mathrm{http}: / /$ repositorium.sdum.uminho.pt/browse?type=author\&value=Rocha\%2C+Joaquim+Freitas. Acesso em 15/12/2013.

SOUSA FRANCO, António L. Finanças Públicas e Direito Financeiro. Volume I e II. 4. ed. Coimbra: Almedina, 2012.

VASQUES, Sérgio. Regime das Taxas Locais: introdução e comentário. Coimbra: Almedina, 2009.

XAVIER, Alberto. Direito Tributário Internacional. 2a ed. Coimbra: Almedina, 2009.

http://www.parlamento.pt/Legislacao/Paginas/ConstituicaoRepublicaPortuguesa.aspx

http://www.planalto.gov.br/ccivil_03/constituicao/constituicao.htm. Acesso em 12/12/2013.

http://www.planalto.gov.br/ccivil_03/leis/lcp/lcp101.htm. Acesso em 13/12/2013. 